\title{
Dwelling in the dearth: Colonia Mexico 68 in poverty \& exclusion
}

\author{
Viviendo en la escasez: Colonia México 68 en la pobreza y la exclusión
}

Tajudeen Oluwafemi Noibi

Universidad Autonoma Ciudad Juarez - México

Ciudad Juarez, México

tajunoibi@gmail.com

Ojeiru Felix Ezomo

Tottori University - Japan

Yonago, Japan

ezomoje@tottori-u.ac.jp

Digvijay Pandey

Dr A.P.J. Abdul Kalam Technical University - India

Lucknow, India

digit1101989@gmail.com

\section{Abstract}

The growth of irregular settlements in Ciudad Juarez has largely contributed to the expansion of the city, where informal city expansion was later transformed to regular urbanization. The reason for this is not far-reaching as the agglomeration of migrants into the city frequently redefined its growth. Simultaneously, the economic significance of the city in the global capital process has further made it a destination point for the engagement of labour from the hinterland of Mexico to central and southern America. This paper investigates the historical context of the emergence of the lived experience amidst poverty and the social exclusion process in Colonia Mexico 68, a settlement to the west of the city of Ciudad Juarez, Chihuahua, Mexico, a vicinity surrounded by multinationals otherwise known as Maquiladoras. The inhabitants are known to be poor and live in poverty and exclusion. The investigation is based on ethnographic research using the Bristol Social Exclusion Model. (BSEM) to measure poverty and social exclusion despite the spatial proximity of the maquilas that empowered the residents. A random sampling of the population was executed through interviews and pictorial evidence. Supporting documented interviews were conducted with the staff of Asentamientos Humanos to further understand the narrative and lived experience of the inhabitants. Luckman and Berger's subjective reality paradigm was adopted in the execution of the ethnographic findings. It was observed that social policy that focuses on education, training, social security, housing, and health provision would further improve the lives of the inhabitants and foster more forms of inclusion.

Keywords: Irregular settlements; Social exclusion; Poverty; Mexico 68

\section{Resumen}

El crecimiento de los asentamientos irregulares en Ciudad Juárez ha contribuido en gran medida a la expansión de la ciudad, donde la expansión informal de la ciudad se transformó posteriormente en una urbanización regular. La razón de esto no es de largo alcance, ya que la aglomeración de migrantes en la ciudad redefinió frecuentemente su crecimiento. Al mismo tiempo, la importancia económica de la ciudad en el proceso global del capital la ha convertido en un punto de destino para la contratación de mano de obra desde el interior de México hasta el centro y el sur de América. Este trabajo investiga el contexto histórico del surgimiento de la experiencia vivida en medio de la pobreza y el proceso de exclusión social en la Colonia México 68, un asentamiento al oeste de la ciudad de Ciudad Juárez, Chihuahua, México, una vecindad rodeada de multinacionales también conocidas como maquiladoras. Se sabe que sus habitantes son pobres y viven en la pobreza y la exclusión. La investigación se basa en una investigación etnográfica que utiliza el Modelo de Exclusión Social de Bristol (BSEM) para medir la pobreza y la exclusión social a pesar de la proximidad espacial de las maquilas que potencian a los habitantes. Se realizó un muestreo aleatorio de la población a través de entrevistas y pruebas pictóricas. Se realizaron entrevistas documentadas de apoyo con el personal de Asentamientos Humanos para comprender mejor la narrativa y la experiencia vivida por los habitantes. En la ejecución de los hallazgos etnográficos se adoptó el paradigma de la realidad subjetiva de Luckman y Berger. Se observó que una política social centrada en la educación, la formación, la seguridad social, la vivienda y la provisión de salud mejoraría aún más la vida de los habitantes y fomentaría más formas de inclusión.

Palabras clave: Asentamientos irregulares; Exclusión social; Pobreza; México 68 


\section{Introduction}

\subsection{Comprehending Irregular settlements}

All over the world the rise of a polarized societies between the rich and the poor are visible both in the global north and south, so much so that the conditions of their being defines how and what they eat, live, and sometimes work. Irregular settlements according to Kamalipour (2016) citing Miraftab \& Kudva (2014) states that they are places borne out of rapid urbanization, rural-urban migration which spur the existence of irregular settlements that close to a quarter of the world's population live in slums. Kamalipour (2016) assertion is a consensus for the growth of slums especially in Latin America, having observed the experiment in Chile for the execution of the neoliberalism market philosophy, hence resulting to a backlash of its implementation in time.

According to Sun and Ho (2015) citing UN Habitat (2003) that "globally, between 30\% and 50\% of residents in urban areas lack legal security of tenure. More than one billion people live in informal settlements, and this number is estimated to grow to 1.4 billion by 2020 ". The cause for the growth of settlements is not largely associated with population growth but with human movements from rural to urban, Periurban to urban movements too. Asserting this, Ambaye that human movements poised the rise informal settlements and,

....according to the UN-Habitat report on global human settlement, slums and urban poverty are not just a manifestation of a population explosion and demographic change, or even of the vast impersonal forces of globalization. Slums are a result of failure of housing policies, laws and delivery systems, as well as of national and urban policies (2011, p. 12).

For Durand-Lasserve and Clerc (1996) irregular settlements restricts the social and economic integration of low-income urban households, making access to credit for housing more difficult. Therefore, the inclusion of socio-spatial distinctions of margins of spatial deficiencies and improvised living in social experiences in some form of gaps and adapting conditions could best describe the condition, though at a reduced productive returns. However, it is also important to understand slums defined by Ambaye (2011) as spatial confines identified with spontaneous, unorganized and unregulated expansion. These growths have somewhat polarized world and the urban situation with two uniquely opposing development, one organized and the other unorganized. Davis (2006) explains some of the visible characteristics of informal settlements namely congested space, informal housing here would mean improvised construction, poor public infrastructure, existence of filth, insecure tenure. He further explains that the definition was adopted by the United Nations Organization meeting of October 2002 held in Kenya. The emphases were on the physical infrastructure and visible conditions, the hardly visible condition was not put into consideration.

Therefore, spaces that lack the geographical connectivity as well social inclusiveness could then be termed as irregular settlements. Durand -Lasserve and Clerc (1996, p. 9) then asserts that "irregular settlement includes a wide range of local situations and dynamics, an area where spatial expansion and occupancy are not in compliance with the urban plan and environmental standards set by public authorities". The earlier submission reclines on the non-compliance with urban building codes. Irregular settlements are places of spatial distinctions, beyond this, it could be termed also as social spaces of identities away from the regular life, social identities of the less privilege within urban confines, where the changes in spatial and social formations and sustenance varies through time and space.

In order to make a living which translates to lived experiences, it is a core area of determining what an irregular settlement is. Irregular settlements provides improvised living conditions such as informal work spaces, which generates income to inhabitants, such spaces even when regularized are not compromised by the owners, neglecting provided spaces for such by government, such spaces are sustained over a long period of time, that not until their social conditions begins to change and their education is obtained whether at formal or informal level do they begin to look regularized.

The identification of those who reside in these peri-urban environment is the lower-class inhabitants. Irregular settlements are known to thrive on illegalities or extra legalities. Kamalipour (2016, p. 63) citing Wattanawanyoo (2012) explains that "the emergence of these major forms of informality are linked to the 
availability of unoccupied land and low rental rate in proximity to areas of convenience. Urban informality is located within areas cities of expansion". This position of urban growth is explained by Rodgers, Beali, \& Kanbur, (2008, p. 8) that,

\begin{abstract}
...indeed, the phenomenon clearly remains significant, although it is now arguably mainly due to push rather than pull factors, as access to social services and labor opportunities in rural areas continue to be much worse than in urban areas. At the same time, the predominant form of spatial movement within contemporary Latin America is undoubtedly urban-urban migration.
\end{abstract}

To Taher and Ibrahim both defines (2014) slums as lands invaded illegally by the poor within urban confines with no form of urban regulation rather built parochially with use of improvised labor and materials and built spontaneously with little or no basic amenity. Taher \& Ibrahim (2014), explains the social status of those who reside in these settlements as poor urban dwellers, thus building poorly constructed houses. This is an assertion to the submission that irregular settlements are a manifestation of the state of living of the urban poor reflecting in their built environment.

Such areas are considered as below habitable conditions, as public utilities makes them out of reach out of regular living. Though, the behavioral pattern this may lead to the creation of social movement, not to necessarily confront the order but for the idea of the survival of others, putting their needs into consideration. Urban edges are devoid of formal activity and are occupied where it is viewed as a place of contrast when compared with the rest of the city, something showing a form of leapfrog pattern. By this it is understood that there is a developmental disconnection like streets and other public utilities. Consequently, these leads to some form of hopeless condition and promotes some level of crime since they are lands devoid of development, isolated place and waste land lived by the poor.

Therefore, this study investigates the historical and lived experience of irregular settlements in Ciudad Juarez, and specifically in colonia Mexico 68, with the objective of the process of how and why they are considered as socially excluded, amidst the opportunity of formal work. This investigation elaborates the subjects of poverty and exclusion within the spatiality of colonia Mexico 68 in Ciudad Juarez, Mexico.

\title{
1.2 Conceptualizing Poverty and Exclusion
}

Understanding Poverty and Exclusion, Backwith (2015) citing Dawn as quoted in Strelitz and Lister (2008) explains that poverty is measured in monetary value, rudimentary needs are barely satisfied or fulfilled. Backwith (2015) citing Ferragina (2013) affirms that poverty is the absence of sustainable income, hence limiting human activities. Chambers (1995) asserts that poverty has myriads of perspectives, one is based on income and financial capability. Hence, poverty is understood through income, and it is analyzed, based on human consumption. Houghton, Jonathan and Khander (2009) affirms that poverty is amplified through unmet needs through related services either social or economic. The manifestation of these state of want is seen in the living style of those caught in the entrapment of poverty. The manifestation comes from through work, housing and even interaction and social engagements within their habitat. Hence, poverty is about been in need and been deprived which affects the wellbeing of the individual and his dependents. They explain that poverty has to do with utility and consumption, from housing, feeding, work, health, education. Poverty has ripple effects on the wellbeing of the individual and his dependents too, which makes them feel powerless and dejected. A feature of the poor is the place they live, where there seem to be of little value for a decent life, with characteristics of high inequality in the standard of living when compared with others, improvising their basic needs.

Generally, poverty rates are higher among single parent household, women, minority, and household with large number of children. A major determinant is the structure of the polity where the social structure can be accounted for at the level of poverty in a system. This determinant defers away from individual contribution and self-will as to how the system has been structured. This idea differs from diligence, where hard work and relentless effort is put aside, as no major factor into 'wheeling off poverty'. In the submission of Sameti, Esfahani and Haghigh, (2012, p. 49) "on the basis of labor wages, functionalist theory accounts for the causes of poverty among certain people and groups in society." Poverty can be distinguished based on income and consumption which is rated as extreme poverty (Dijeterlen, 2005, p. 
19). These explains why nations and societies may have remained poor for some time, and not until the system is re-worked, all inhabitants would remain poor. Some systems are programmed to assist into the discovering of potentialities, so much so that it maximizes for the purpose of profit making. One major country to look at is the United States of American society where there are Ivy based leagues to encourage athletes and gifted youths into making a career off their talents.

The poor is excluded from regular social benefits as capitalism is centered and benefitting for the upper class, as a source of wealth with the ability to make and afford which the poor obviously can only do little. According to Gomes (2012) citing Amartya (1999) defines poverty as the,

...deprivation, since low level of income affects people's capabilities in education, health, survival, work, and other variables. Moreover, poverty is lack of income, but it is also a lack of capabilities since an adequate income level is not the only generator of capacities. Social justice implies eradicating poverty, promoting capabilities and liberty to make decisions (2012, p. 37)

The relationship between income and capabilities varies among families and individuals. The poverty phenomenon in the context of Latin America specifically is aggregated over such a lag such as education, health services, and social security.

The absence of physical necessities, and income, which leads to isolation to be precise, exclusion. A critical assessment of poverty raises the question about it that policy of nations tends to account for its benchmark and encroachment. Economic policies and structure could well determine who and how inhabitants fall into poverty. A major factor that has strengthened poverty over time was identified by Sameti, Estahani and Haghigh (2012) citing Gans, (1995) that neoliberalism and free market, gives almost the same opportunity, irrespective of one primordial ties and creed. Human basic needs seem to be man's first pressing need. In the human contest guided by little rules, it becomes a relationship of win all or lose all.

\subsection{Understanding causes of Poverty and Exclusion}

There are two almost non-independent themes in the global south, exclusion, and poverty. Non-access to the basic necessities of life like good roads, education, health care, employer, housing, and many others, explains both. This problem shuts out a section of the urban populace either through structural issues relating to poverty, institutional positions or even through the culture of poverty. It creates a kind of friction and shock wave between two identities of the underprivileged and the favored. Saraceno posits that,

...poverty and material deprivation on the one hand, reviewed in the light of social rights thinking; social disintegration, marginality, un-belonging, up-rootedness and so forth on the other hand. Thus, on the one hand it points to the social conditions by which individuals and groups are included in or excluded from relevant resources and particularly social rights; on the other hand, it points to processes by which individuals and social groups belong to, or are detached from, relevant and meaningful social networks and share in the values and identifications within a given community (2001, p. 6).

Poverty and social exclusion are very much interconnected, where the capacity to afford the basic needs of life such as social services and education would require some form of financial capability especially when is privately and commercially driven. The position Backwith (2015) is corroborated by Fisher, Mc Cann, and Aureyo, (2014, p. 7) that "social exclusion can be constitutively a part of capability deprivation as well as instrumentally a cause of diverse capability failures" (Sen, 2000, p. 5). Therefore, wonder if social exclusion causes poverty and slum housing or if it is a consequence thereof. Exclusion can bring about other exclusionary consequences, while a policy of inclusion can have the negative effects of exclusion. These challenges different levels of government through the study of various policies. Mapping how exclusion and inclusion processes permeate spatial, economic, political, and social-cultural dimensions provides an understanding of how urban policies have been developed and implemented, as well as of 
their impact polarization, discrimination, poverty and inaccessibility. Exclusion is a process and a consequence of some set of actions leading to consequences. It is not a physical construct but a result of a social construct. The mutually dependent nature of poverty and exclusion creates enforcing role. Social exclusion becomes clear when analyzed, especially very much knowing that it does not necessarily have to be naturally disconnected to poverty.

To De Boyser et al., (2009, p. 22) social exclusion is thus a "generic concept that refers to various situations and processes such as polarization, discrimination, poverty and inaccessibility". Social services and basic human related activities that social exclusion is found are labor, education, housing, health, administration, justice, public services, and culture. While linking the idea of lessening individualism as a pre-determinant of poverty alleviation, inclusion, and wealth creation. As the case is with neoliberalism and capitalism where free will and individualism which promotes survival and limits structural policy of welfarism neither does it promote dependency on state resource and non-reliance on state resource or safety net.

Social exclusion is understood as an expression of social disintegration and of individual detachment from the social order or as a lack of minimum rights, that link is by no means necessary (Saraceno, 2001:06). A report of researchers on social exclusion executed by the office of Deputy Prime Minister of the United Kingdom (2004). These mutually dependent variables are income and poverty, employment, education, and skills; health; housing; transport; crime and fear of crime; social support/social capital, the impact of the neighborhood, financial services, social services, leisure services, or civic participation. Backwith citing Ferragina et al., explains that social exclusion is "poverty-related which describes the process by which people, especially those on low income, can become socially, politically and economically detached from mainstream society" (2015, pp. 6-8).

The role of geography, culture, and economic variables in the discussion of poverty. According to Sowell (2015) explains that it is difficult to isolate the contribution of geography as performing a role of poverty and prosperity. The web-like connection with other variables where geography plays a more dominant role is evident. Sowell (2015, pp. 2-3) explains that "mountain regions discourage the budding of genius because they are areas of isolation, confinement, remote from the great currents of men and ideas that move along the river valleys". Such isolation with the low humid and most likely infertile land only translates to poverty. The isolation of such people living in these areas breeds conservative and sometimes hostile nature as it affects not just the economic but the socio-psychological behavior and finally becomes cultural. Also, the nexus between isolation and poverty is complimentary.

This explains the nature of Tarahumara ethnic group, where they live in poverty and exclusion. They reside, cohabit, and cultivate on mountain tops. This is not only visible with Tarahumara, the location to waterways, seaports also promote interaction with other civilization, promoting economic development. Rio Grande water passage have somewhat facilitated the agglomeration of people, the Spanish and British colonial masters saw it as imperative to conquer the people of the border area and extending its dominance. Also, geography sometimes puts locations and what is contained in the soil as somewhat beneficiary for a community.

Education has been heavily monetized in the neoliberalist era with so much financial burden on the learner and their ward. Social exclusion becomes inevitable, thereby producing low skill workers and unemployment in large numbers. This is supported by Serecano that "social inclusion means extending access and transforming the social security and social protection system" (2001, p. 8). In the Postmodern age, social exclusion would easily manifest in unemployment, education, health care and other areas to which has a large membership base and creates inclusion at some level other end in response to their situation in the society, same goes with habitation, security which binds all urban dwellers. It identifies as part of the coping strategies to promote survival but does not necessary break them away from poverty. However, generational poverty is biological and generational sustainability of poverty, where it is seemed to be cultural in nature.

Thus, it is very difficult to assess the impact of a national policy with the study of a single neighborhood since local factors can be more explanatory than higher-level factors. Attitude, believe, occultic traditions defines space for the poor as itemized in Fisher, Mc Cann, \& Aureyo, "It includes not only the physical, three-dimensional space, but more dimensions that give it its social, cultural and political properties" 
(2014, p. 8). Since Lefebvre's, The Production of Space (1991) and Harvey's Limits to Capital (1982), space is usually considered as a social product which, in a critical/Marxian approach, is seen as a potential source of injustice, inequities, accumulation and exploitation. "In addition to be a means of production it is also a means of control, and hence of domination, of power" (Lefebvre, 1991, p. 26). Without necessarily adhering to this politically engaged view, all geographers and spatial scientists consider space as a system of relationships, between places and between people. Space is not only determined but determining, "color of hair and eyes, all be it, that the differences do not impact on income, power or status, where social exclusion is fragmented spaces with distinctive physical spaces or spatial entity but with equivalent". De Boyser (2019) explains that to create a social relation would on the immediate outcome creates an identity, the submission relates to Marx`s idea of capital and class consciousness, where the idea of the others emerges and later progresses to 'us and them'.

Diagram 1. Relationship among elements

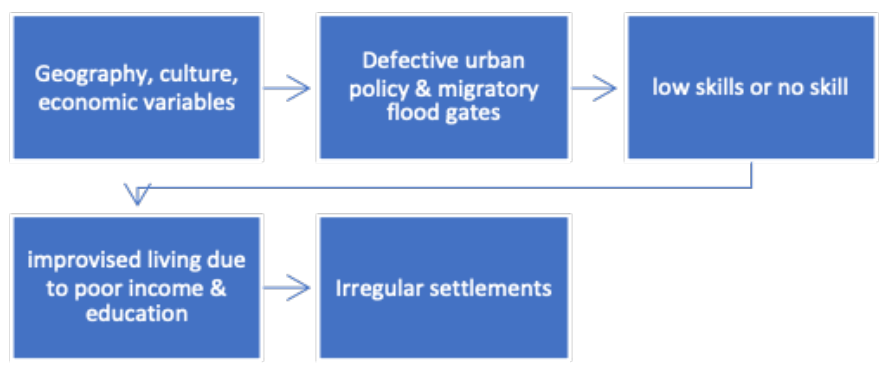

Source: Noibi (2020)

Levitas, Pantazis, Fahmy, Gordon, Lloyd and Patsios (2007) categorizes participation and education. Based on this paradigm a measuring matrix was created. Resources is the first method of measuring using B.SEM. Material and economic resources, such as access to financial institutions and credit facility, public services such as public utility of water, sanitation, electricity, telecommunication, gas. furniture and home appliances. The second one is the participation, culture, education, and skills political and civic participation. This evaluates the level of education vis a vis cultural process of everyday life, kinds of jobs they are involved in, social cohesion and participation and the type of association they are involved in. The political views as it is related to their needs. The last one has to do with their quality of life, health status and challenges, what is consumed in meals and drinks in relation with the health and biological benefits. These bothers on immediate environment, very much looking at issues of sanitation, crime and likelihood for criminalization and deviance. The three categories are areas of risks that submerges individual and groups into exclusion. However, it is important to factor in relations to socio-economic conditions that could give a false pretense of the categories.

Irrespective of the cause, slums are a way of settling housing needs through self-help, influenced by the rush to belong to the ever-growing cities where global capitalism and the role of each city becomes distinct in the new order, guided by open market and democratic of politico-economy system. While the will to make more in human needs and as technology grows, rural areas became short of human activities, as the wish to belong to glamorous urban life is a motivating factor. Corroborating the earlier submission, Law asserts that "the wealth that may have gone to the state was redistributed and concentrated in the possession of private investors who have invested in public services, thereby amassing wealth while the" (2018, p. 25). This has created a problem for the poor in the quality of life they live, where "the poorer classes with meagre income have difficulty to access".

Inequality is dependent on wages from employment or been unemployment, where life seems to mean very little and when little is done. Inequality did not start with unemployment or low skill which attracts very low wages. It could emerge from the basic of poor cultural capital, where the lines of value and orientation of how the elite's lives life and how the poor rationalizes it too. This would somehow create a lock up of the poor' in a cyclical manner that would be difficult to curb. Lack of access to the basic needs of life, especially where naturally value is placed on knowledge and pursued as it relates in the regular urban life such as what to eat alone and get involved in less productive matters when compared to neighborhoods 
of the elites. Lichter, Parisi and Taquino citing Clark and Ledwith; Iceland (2009); Reardon and Bischoff (2011a) states "to be sure, poor people live disproportionately in poor areas where they can best afford to live, especially during hard times". Parisi, Lichter and Taquino (2011) 74 Backwith, (2015) explains the different dimensions of poverty, noting that the general believe of poverty in material wellbeing is facial and should be viewed with deeper insight into other trajectories.

\subsection{Historical development of Irregular Settlements}

In the case of Ciudad Juarez similar with Mexico City evidence shows that the growth of the city contrasted with the earlier submission as it emerged through informal land acquisition, where the poor resides. Connolly, \& Wigle, (2017, p. 185) submits "in Mexico City, over half the population, including much of the middle class, can only access housing through informal or irregular settlement processes, either because of their income". This situation reflects Mexico's longstanding social inequality combined with the absence of a more comprehensive affordable housing policy. One the reasons for the rise of human settlements in the north of Mexico was borne out of national policies within the country that were largely influenced by economic restructuring of the mid 1980s, austerity measures as migration into the cities began opening to the 'flood gates' of people. The social status of these movements was largely made up of low skilled workers, who were in search of better living conditions in the cities. Latin America was not left out of the phenomenon. Mexico, a country located in the north of the North American continent, yet Latin in culture benefits from the proximity with countries such as United States of America and Canada. The northern region of Mexico with cities such as Tijuana and Ciudad Juarez as border cities between Mexico/United States have long witnessed migratory movements with the unique location, makes it convenient for settlement dwellers to locate homes along the border, yet spatially far away from the city center. These was pivoted by the industrial growths along the border. The submission of Woods (2001, p. 57) that a colonia is an irregular settlement "defined as communities situated outside urban centers where it is believed that owning a house of their own is paramount, they are built through improvised skills and social networks." They usually lack good structural planning and adequate human and material resources to build. Historically, Woods (2001) attests that migrants, farm workers, and low-income residents make up a large proportion of settlers. He observes that as far back as 1960 to 1980, agricultural and manufacturing industries where are the forefront of those in the demography of irregular settlers.

The account is credited to Quijada (2005) that around 1940-1960 there was an unexpected rise in the population of inhabitants who lived in Ciudad Juarez which rose to about $591 \% \%$ in $1948,682.5 \%$ in 1984 which became a hand full in terms of public utility to the municipal government of Ciudad Juarez. Quijada (2001, p. 386) states "even though it was a new problem for the municipal authorities, they responded differently.

Quijada (2005) recalls that the earliest months of 1953, colonia Chavena was established which was found to be a dump site and was later cleared for the construction of homes. High publicity was giving to the development then as questions were raised and permission was granted for the settlement to exist while others were given sometime to resettle elsewhere by the municipal authority. According to Quijada (2005) who explained that around 1940-1960 there was an unexpected gargantuan rise in the population of inhabitants who lived in Ciudad Juarez which rose to about 591\%\% in 1948, 682.5\% in 1984 which became a hand full in terms of public utility to the municipal government of Ciudad Juarez.

\section{Methodology}

The research employed the qualitative research methodology, executing the process through ethnography. Luckman and Berger philosophical subjective paradigm was adopted. Random stratified sampling method was employed, selecting male and female respondents cutting across those that at earn a living in formal and informal sectors of work. Ethnographic research was Implemented on two families with their extended members Observation of the respondents and the habitat was utilized to facilitate the submission of the interviews. The findings were supported with archival documents, interviews with related organizations such as Asientamiento Humanos, Instituto Municipal Investigacion Planeacion. A polygon was also used as a form of pictorial evidence to explain and support the claim. 


\section{Discussion and Results}

According to IMIP (2009) the polygon is in the west of Ciudad Juárez, where Mexico 68 colony belongs. The main roads to access the area are to the west, the Av. De los Aztecas, to the south General Ponciano Arriaga and to the east along the Juan Gabriel Axis. By disaggregating the population by gender, it is composed of 1,025 females and 1,044 males, which when dispersed by age, the greatest number of inhabitants for the area is concentrated in the group of 15 to 59 years old, with 611 women and 607 men.

The second group with the highest concentration of inhabitants corresponds to people from o to 14 years old, of whom 365 are men and 611 are women. People who are over 60 years in the colonias are of the minority of inhabitants within the study area with a disaggregated by gender of 45 women and 46 men. Regarding the data referring to education of the inhabitants it was observed that the disparity between genders is minimal; when relating it to the total of men and women, the population of 6 to 14 years do not attend school, which manifests with 10 women and 9 men.This same gender phenomenon is observed in the population of 8 to 14 years of age who cannot read nor write, being 3 women and 2 men are with this condition. However, when observing the population of 15 years and over, are without education, the distribution is tied with 33 women and 21 men.

The right-holder in the population is distributed with 1,317 people with social safety net in with Institute Mexican Social Security (IMSS), as 58 people enrolled in Seguro Popular, being as beneficiaries of the Institute of Services and Social Security for Workers of the State (ISSSTE) only 10 people. In conclusion, 588 people are observed in the area without no health service, which shows marginalization of health services in percentage $44.64 \%$ of inhabitants who are in that condition. Housing with poor roof and wood were located where a stream passage.

The settlement is located at the west of the city, where there are less hills, however, rocky. Some area to the west has stream flows, and highly industrial as the area is known as the place of the 5 maquilas. While the place is close to the business areas of Ciudad Juarez. The remote area has the rail paths that moves at the preliminary edges of the settlement. The road that leads to Mexico 68 is sloppy and curves. Just across the railway lies a maquila and an informal market. As regards the earliest settlers, records from the Public Registry on Properties indicate that Magdalena Garcia Marcado, Maria Elvia Rangel Caro and Silva Rosa Valencia registered the land as theirs in 1994 after governmental efforts to regularize the property. Others are Luz Maria, Octavia Munoz Correl, Enrique Cordova Reyes. The municipal authority also bought $15 \%$ of the land from their owners to be resold with planning rights to other inhabitants.

The living pattern of the inhabitants revolves around two major elements: the maquila and informal trade. Perhaps less is the informal trade as compared to the maquila close by as gathered by my interviewees. Most inhabitants of Mexico 68 work at the 5 maquilas, where they earn their living and associate with fellow workers. Most of the workers consume their free meals at the maquilas and are conveyed by the bus of the firm to the closest place of stop. After closing, they tend to retire for some few bottles of beer and chats before retiring for the day.

Elena is 52 years old. She also works at the maquila, she attended primary school, she is moderately bilingual, she makes 1200 Pesos per week. She has no access to the bank but saves a bit from the amount per week. She explained that she will be retiring from the maquila at the age of 60 years and would have access to her pension. She transports herself to and back with commercial truck from 6 am-4pm, Monday to Friday. She has 2 children, one of them sells used items. She explained that at a time in her life she was working at 2 maquilas at the same time. She explains that she bought her land 30 years ago at 3,000 Pesos. She commenced the construction of her building in bits for over the last 30 years. In the process of investigating, her only son who works at the maquila and comes home during weekends heavily drunk. Her son works as a casual laborer at a construction site.

In a separate interview with Elena's son-in-law confirmed that he sells dry food in an informal market for a living. He explains that the colony across is very dangerous, so he avoids going there. He has a wife and 2 children. He buys his dry food in bulk form downtown to sell in dry form in the colony. He explained that he is from the south of Mexico specifically Vera Cruz, he used to live in a bad condition but now lives in better condition. 
Family cohesion seems to be in jeopardy. She explains further that she takes her ill child to the hospital as early as $5 \mathrm{am}$ in the morning. She explains that she would love to resume working at the maquila when compared to selling at the informal market as it has become dangerous due to the bad weather. She has domesticated the rearing of rabbits in the home and pays 100 Pesos on electricity every month. She further reiterated the need that during winter she usually buys wood to heat up her one bedroom with logs of wood for the price of 30 Pesos to be used for 4 days. Looking at the floor a label of SEDESOL was noticed which she said that the concrete was done by the government agency about 3 years ago. The outer compound was not concreted but the main street was concreted 3 months.

The father of the lady, he seems to have been infected of cold issues, as age seems to be a factor due to low immunity. He is also infected with cough. He explained that he has little to spend on food as the girl supports him. During my interaction with Elena, she mentioned that there is a social program called which gives loans and school materials to parents who have children and needs financial support. She claimed that they only give loans to those who are literate but for her she is not as she only attended elementary school.

In all the interviews conducted within the settlement, the level of education and the research findings, showed that the lowest is no education to the highest which is secondary education. However, their education competence is relational to their employability and the capacity to perform job designation set of tasks. Most of the respondents who were asked why they did not finish school or further in their studies, they all mentioned financial incapacity.

In my further interaction with others who are in the informal business of pawn swap shop and informal trading named Fernando, he claims sales are frequently bad and that till late in the evening he had not taken breakfast nor lunch. Inquiring further, he explained that he would not be able to work at any maquila due to old age as almost all younger people in the Colonia do.

He told that he was 73 years of age. He said all day he had only made 15 Pesos worth of sales which was observed at different times, people just came to window shop and not buy anything specific. He expressed heavy frustration and hopelessness with his condition. He claimed he cannot afford gas supply during winter, so he uses only blankets to brace up the cold.

The below table is a summary of the elements found in the irregular settlements, see table 1.

Table 1. Summary of found Elements.

\begin{tabular}{|c|c|}
\hline Elements & Mexico 68 (West) \\
\hline Influencing Environment & 5 maquilas \\
\hline $\begin{array}{l}\text { Average no of dwellers/ average inhabited rooms of } \\
\text { respondents }\end{array}$ & $5-7 / 3$ \\
\hline Spatial arrangement & Bad arrangement of houses \\
\hline Age range of interviewee & 21-75 years \\
\hline Disparities of work and ways of income & $\begin{array}{l}\text { Maquila, sales assisting, informal trading, construction, food } \\
\text { seller. IMSS }\end{array}$ \\
\hline Range of income per month & 0-440o Pesos \\
\hline Commoditization & No evidence of credit inclusion \\
\hline Dependence on cash economy & Evident \\
\hline Present public utility & Water, electricity \\
\hline Absent utility & Bad inner roads, no connection gas provision \\
\hline Deviance attitude/illegality/ Extralegality & Shoes on electric poles, noise disturbance and drunkenness \\
\hline House condition & Not fit for living \\
\hline construction history & 7-10 families constructed (improvised) and some cases self-built \\
\hline Asset indicators in the homes of interviewees & Low presence of cars, proper toilets, roofing, and heaters \\
\hline Socialization & Strong family cohesion \\
\hline Condition of acquisition of land & Legal (claim) \\
\hline Observed condition on acquisition & Observation of likely discrepancy \\
\hline Education (lowest to highest) & Nil-secondary and some level of illiteracy \\
\hline Health condition of respondents & Poor \\
\hline
\end{tabular}




\begin{tabular}{|l|l|}
\hline Terrain & Rocky, windy, and cold \\
\hline Length of Stay in habitat & Largely more than first generation \\
\hline Identity of citizenship & None \\
\hline Parks and Gardens & None \\
\hline
\end{tabular}

Source: Noibi (2020)

Bristol's Social Exclusion Matrix (B.S.E.M) is classified to resources, participation, and quality of life. See table 2 as displayed below.

Table 2: Bristol`s Social Exclusion Matrix (B.S.E.M)

\begin{tabular}{|l|l|}
\hline $\begin{array}{l}\text { Classification/ } \\
\text { Colonias }\end{array}$ & \multicolumn{1}{c}{ Mexico $6 \mathbf{8}$} \\
\hline Resources & $\begin{array}{l}\text { Presence of basic needs like refrigerators, cars, flooring, toilets, roofing and unit improvised wood } \\
\text { heaters. Availability of electricity, water though and public transportation, however with narrow inner } \\
\text { gully roads. Community Parks cannot be identified. No evidence of credit inclusion. Dependent on cash } \\
\text { economy }\end{array}$ \\
\hline Participation & $\begin{array}{l}\text { There have been first generation inhabitants still living in the colonia. Social cohesion and participation } \\
\text { is present. Also are religious participation within the community }\end{array}$ \\
\hline Quality of life & $\begin{array}{l}\text { Health condition as observed are largely due to issues with cold, due to the level of humidity and long } \\
\text { working hours of stress due to the maquila demands. House condition barely habitable. Crime and } \\
\text { deviance are regularly witnessed }\end{array}$ \\
\hline
\end{tabular}

Source: Noibi (2020)

Land ownership policy across all arms of government within Mexico is distributed across federal, state, and municipal government. In the case of the federal government, land situated closely at the edge of the border are directly owned by the central administration. Aside this, land and buildings situated in central areas are owned by the central government for office use and other exclusive uses. The state government also possess land for offices and urban related matters such public services, as land for housing schemes. The municipal government of Ciudad Juarez owns $15 \%$ of the land meant for services and for effective planning.

The adherence to the $15 \%$ ownership of municipal land as provided by law and later resold for the provision of public services. However, true, evidence from documentation unit on land along with insights from Asentamiento Humanos attests that true was the earlier position but a panoramic and investigation executed observed that there was evidence to prove that some public servants acquired land in the 1990 just to later put on sale to the poor to create settlements. There may have also been a level of connivance between the aristocrats and the middle level public servants to further acquire vacant lands only to be documented by the aid of middle level of public servants. The diagram below further explains the instrumentalization of the border lands for either political or economic gains.

In a separate interview dated $17^{\text {th }}$ February 2020, Gilberto Vazquez a Topographer for Asentamiento Humanos explained The Topographic Officer named Gilberto Vazquez_in an interview on $17^{\text {th }}$ of March 2020 explained that his unit works together with the Public Register of Property, Civil Protection, Public Works, Municipal Water and Sanitation Board, Federal Commission of Electricity and Human Settlements to make the topographic survey for the viability of public utilities in the colonias. There are municipal colonies that were planned and agreements with individuals were all the services exist, school, parks and water services, electricity, and drainage.

Former administration has relied on the political influence of these settlements through compromise of the interest of the dwellers with great capacity of helping people that requires a land titling, but lose conviction when accepting colony leaders, cronyism, leaving the citizen with problems such as land 
titling, public utilities, and infrastructural deficit. This is because since the political aspirants influences the leaders in the colonies only for the purpose of personal interest leaving the settler in trouble with issues that bothers on the daily and communal life which reflects on the social and economic being.Majority of those who reside in irregular settlements are low-income earners who because of their needs allow themselves to be led by colonial heads to be maneuvered by the greed of those at the city council, hence creating a problem for Asentamiento Humanos Gilberto affirms that irregular settlements in more cases bring their own culture from their birth place.

The ripple effects of land acquisition and land use in Ciudad Juarez in the year 1995-2016, as more maquiladoras and irregular settlements due to migration and complimentary spaces that becomes the implications of location for business to the ever-consuming capital of the world, such as the thriving border informal markets. This is substantiated by the submission of Pena and Fuentes (2007) that two elements pivoted urban growth within Ciudad Juarez which are industrialization and migration. Though, migration has always been an occurring phenomenon in the city, uniquely, the industrialization through the global capital place of the city of Ciudad Juarez has exacerbated the pattern land use with intensity.

It is of importance to state that during the late 1990s to the early 2000 s witnessed the rise in crime in the city of Ciudad Juarez. The movement of people away from the city to other nearby cities was a consequence of this crime. Eisenhammer (2014) asserts that the state failing in meeting the rising needs of its people where urban disenfranchised leading to a space belonging to exclusion outside such as Pancho Villa turned from smuggler to a revolutionary was a reactionary action to the deteriorating living condition in Ciudad Juarez. To sever and situating the location of the city to the global capital system where it benefits a small fraction of capital with the ever-rising demand of urban services complicates the rise in crime. This submission is not creating an ethical position but a semantic explanation to the problem that comes with industrialization.

\section{Conclusion}

It will be unfair not to commend the efforts of the municipal government and related agencies as they try to ameliorate the problem of poverty within spatial entities of irregular settlements. Deviating slightly, findings within the settlements explains that problem of how poverty persists within the three colonias under study. Though, when viewing poverty from the position of income, it may be difficult to access alone through it. Further studies within the settlements indicates the gap of education found in the settlements of Anapra and Mexico 68. Largely those interviewed possesses very little education that may not suffice in their day-to-day activity. The physical structure, morphology, and the built environment is visible to identify as an irregular settlement, such as public services and planning codes.

Two elements have made the city popular as a point of destination for migrants. One is the location of the city and the other is the influx of multinationals thriving in the city. Location of the city has been one of the most potent resource of the city. The location of the Rio Bravo river in the edges of the city have made it attractive for agricultural production and the survival of the inhabitants. The introduction of the Braceros in the late 1940s. This was majorly targeted to improve the agricultural productivity of the United States of America at the expense of cheap labor of Mexicans, who needed income. The city shares boundaries with the city of the El-Paso, Texas, United States of America. The United States of America is known as the capital center of the neoliberalist ideology. The exploitation of these people has further continued to subject the border community to some form of precarity, leaving spaces of implications and manifestations, a further reflection of the state which the poor finds themselves.

The intensity was fostered by the political and administrative arm of government, as they have either instrumented or have made some form of weak challenge to stem the tide as at the time irregular settlements sprung up. This have somehow taken a beneficial, yet seemingly parasitic position in terms of access, production, and labor. The selection of the city as a global capital resource have been intensified due its human resource, as the labor to generate capital is cheap and easy to access without much bureaucracy. The provision of a suitable job opportunity for a large population of people to get out of misery may have forced government to take this lenient position. However, the ripple effects have sustained the tradition of irregular settlements. 
In the case of Mexico 68, the settlement is unique as it relates closely with some set of maquilas to the west of the city. The settlement is largely quiet during the day as most of those who live in the settlement are largely workers at the nearby maquiladoras. The inclusion and exclusion process may be difficult to comprehend. Proximity to the maquiladoras indicates that some public services were provided for the inhabitants. However, their everyday lived experience does not conform to the regular urban life. Identifiable in the discussion is the meagre pay earned by workers in the maquilas with very low education and skills. Investigation executed reveals that income made during the week is expended on alcohol and frivolities as the idea of 'next week paycheck will come' is the idea that is transmitted from one generation to the other. The need to socially disentangle themselves form their places of work, is promptly done and all formal means to expand and express formal opportunities are unavailable and resented by them. Therefore, their place of work is like a paycheck and not an informal learning place or skill acquisition center. The conditions of living in Mexico 68 is deplorable with no gas supply. In the critical time of winter, logs of wood are used to warm up their habitat. Electricity supply is stable within the settlement, pavements, streetlights, and water is regular. However, the inhabitants largely claim the water is not consumable.

However, the problem of aid to uplift the living conditions is good but addressing the problem through empowerment seems relatively downplayed. Largely the employment found are also reflective of the living conditions in general such as informal trades, maquila jobs and constructions workers. In the case of Mexico 68, the roads are largely deplorable which is caused by the trucks that moves equipment into the maquilas and back. While some of them are registered for the social security, Instituto Mexican del Seguro Social (IMSS). In conclusion, social exclusion is apparent through the educational, social security and employment gaps while inhabitants interviewed have expressed their lack of trust in the municipal government.

\section{REFERENCIAS}

Alegria, T., Barba , G. (2016). Legalizing the City: Informal Settlements in Regularization Process in Tijuana. El Colegio de la Frontera Norte.

Chambers, R. (1995). Poverty and Livelihoods: Who Reality Counts? Environment and Urban, 7(1). 173-204. https://doi. org/10.1177/095624789500700106

Connolly, P., \& Wigle J., (2017). Constructing Informality and Doing Regularization in the Conversation zone of Mexico City. Planning Theory \& Practice, 18(2). 183-201. https://doi.org/10.1080/14649357.2017.1279678

Daniel, T., Litcher., DomenicoP.,\& Michael, C. Taquino. (2012). The Geography of Exclusion, Race, Segregation \& Concentrated Poverty. Oxford Press.

Davis, M. (2006). Planets of Slums. Verso.

Dijerterlon, P. (2005). Poverty: A Phliosophical Approach and Philosophical Studies. Rodopi.

Durand-Lassavre, A. (2006). Informal Settlements \& The Millenium Developement Goals. Global Policy Debates on Property Ownership and Security of Tenure. Global Urban Develoement. 2(1). 237-254. https://www. globalurban.org/GUDMago6Vol2Iss1/Durand-Lasserve.htm

Eisenhammer, S. (2014). Narcoculture and the Politics of Representative Barelife in Ciudad Juarez in Ciudad Juarez: Violence in a Space of Exclusion. Sage.

Elena, T. (2019, January-August 19th). Living Conditions in Mexico 68. (T. Noibi, Interviewer)

Fisher, B. (2014). Cities From Scratch: Poverty and Informality in Urban Latin America. Duke University Press.

George, J. (2018). Are Informal Settlements Boon or Bane? In I. Kucina, Informal Architecture.

Gomes, C. (2012). Family and Inequalities in Latin America and the Carribean. Social Science Mind Scientific Research, 3(1). 25-32. http://dx.doi.org/10.4236/sm.2013.31005

Harvey, D. (1988). Social Justice \& the City. Blackwell.

Houghton, A., Khandker, J.,\& Shahidar, R. (2009). Understanding the Determinants of Poverty: HandBook on Poverty and Inequality. World Bank.

Johoel-Gijsberg, G. (2007). Explaining Social Exclusion: A Theoretical Model Tested in The Netherland. The Netherlands Institute of Social Research/SCP.

Kamalipour, H. (2016). Forms of Informality and Adaptations in Informal Settlements. International Journal of Architectural Research, 10(3). 60-75. https://archnet.org/publications/10792 
Kucina, I. (2018). What is the Concept of Architecture of Informality.

Lefebvre, H. (1991). Critique of Everyday Life. Verso.

Levitas, R., Pantaers, C., Fahmy, E., Gordin, D., Lloyd. \& Pastios,D. (2007). The Multidimensional Analysis of Exclusion. Departmeent of Sociology \& School of Social Policy Townsend Center for International Study of Poverty. University of Bristol, Department for Communities \& Local Governance.

Lewis, O. (1966). The Culture of Poverty. Scientific American

Lorrain, J. (1989). Theories of Development: Capitalism, Colonialism, and Dependency. Policy Press.

Massey, D,\& Denton, N. (1993). Segregation and the Making of the Urban Class from American Apartheid.

Peace, R. (1991). Social Exclusion: A Concept in Need of Definition. Knowledge Manangement Group. Ministry of Social Policy .

Planeaceon, I. (2009). Polygon 1. Polygon of Estralla del Poniente. Insitituto Municipal Investigación Planeaceon (IMIP).

Quijada, G. (2005). Politicas Federales E Intervencion Empresarial en la Configuracion Urbana de Ciudad Juarez (1940-1992). Ciudad Juarez.

Rodgers, D., Beah, J., \& Kanbur, R. (2017). Latin American Urban Development into the 21st Century: Towards A Renewed Perspective on the City. Palmgrave Macmillan.

Pena, S., and Fuentes, C. (2007). Land Use Chnages in Ciudad Juarez, Chihuahua: A Systems Dynamics Model. Estudios Frontier (pp. 65-89).

Sietchiping, P. (2004). Caliberation and Validation of a Proposed Informal Settlement Growth Model. 7 th Agile Conference on GIS, Parallel Seesion. Heraklin.

Sun, L., \& Ho, P. ( March, 23-27 2015). Linkage Land Tenure \& Use for Shared Property; An emerging Phenomenon of Informal Settlements in China, a Small Property Rights Housing in Urban Villages and Peri-Urban Areas. 2015 World Bank Conference of Land \& Property (pp. 43-62). World Bank.

Taher, M., \& Ibrahim, A. (2014). Transformation of Slums and Squatter Settleements: A way of Sustainable Living in the Context of 21st Century Cities. American Journal of Civil Engineering \& Architecture. 2(2). 70-76. http://pubs. sciepub.com/ajcea/2/2/3/

Vazquez, G. (2020, February 2020). Topographer. (T. Noibi, Interviewer)

Veltmeyer, H., Petras, J, \& Vieux, S. (1997). Neoliberalism and Class Conflict in Latin America: A Comparative Perspective on the Political Economy of Structural Adjustment. Macmillan.

Wigle, J. (2010). Social Relations, Property and Peripheral Informal; Settlement: The Case of Ampliacion San Marcos. Mexico City. Urban Studies Journal, 47(2). 411-436. https://doi.org/10.1177/0042098009351189

Wood, A. (2001). Anticipating the Colonias: Popular Housing in El-Paso \& Ciudad Juarez 1890-1923. Journal of SouthWest, 43(4). 493-504.

\section{Conflict of interest}

No potential conflict of interest is reported by the authors.

\section{Funding}

No financial assistance from parties outside this article.

\section{Acknowledgments}

$\mathrm{N} / \mathrm{A}$ 